\title{
Seizure of Property as a Way to Ensure Compensation for Damage Caused by a Crime: Theory and Practice*
}

\author{
Dmitriy Aleksandrovich Ivanov ${ }^{1}$, Marina Vladimirovna Sokolova ${ }^{2}$, \\ Oksana Leonidovna Podustova ${ }^{3}$, Pavel Vladimirovich Fadeev ${ }^{4}$, \\ Alexey Yurievich Molyanov ${ }^{5}$
}

${ }^{1}$ Moscow State Institute of International Relations (University) of the Ministry of Foreign Affairs of the Russian Federation, MGIMO-University, Moscow, Russia, 2,3,4,5 Moscow University of the Ministry of Internal Affairs of Russia named by

\section{V.Ya. Kikot (Moscow, Russia) \\ 10.15408/jch.v9i2.21737}

\begin{abstract}
The authors consider the theoretical provisions and analyze practical examples of the activities of the investigative bodies to seize property in pre-trial proceedings in criminal cases. The relevance of this topic is determined by the fact that one of the priority activities of the preliminary investigation bodies at present is to ensure the rights and legitimate interests of citizens against criminal encroachments. The possibility of compensation to victims of harm caused by a crime in criminal procedure law is a guarantee of protection of these rights and contributes to the implementation of the purpose of criminal proceedings. Based on the results obtained, the authors conclude that it is necessary to further improve the law enforcement practice and the norms of criminal and criminalprocedure legislation in order to improve the efficiency of solving problems of identifying property that can be seized. In this connection, it is proposed to amend Part 3 of Article 104.1 of the Criminal Code of the Russian Federation, providing for the possibility of confiscation of property, regardless of the awareness of the causal relationship between the committed act and the presence of money or other property.
\end{abstract}

Keywords: Criminal proceedings; Measures of procedural coercion; Investigator; Inquirer; Civil claim.

\footnotetext{
* Received: February 12, 2021, revised: April 16, 2021, accepted: June 18, 2021, Published: 31 August, 2021.

1 Dmitriy Aleksandrovich Ivanov, Moscow State Institute of International Relations (University) of the Ministry of Foreign Affairs of the Russian Federation (MGIMO-University). ORCID: https://orcid.org/0000-0002-2023-3771

${ }^{2}$ Marina Vladimirovna Sokolova, Moscow University of the Ministry of Internal Affairs of Russia named by V.Ya. Kikot. ORCID: https://orcid.org/0000-0001-6812-8447

${ }^{3}$ Oksana Leonidovna Podustova, Moscow University of the Ministry of Internal Affairs of Russia named by V.Ya. Kikot. ORCID: https://orcid.org/0000-0001-8247-9825

${ }^{4}$ Pavel Vladimirovich Fadeev, Moscow University of the Ministry of Internal Affairs of Russia named by V.Ya. Kikot. ORCID: https://orcid.org/0000-0001-5767-0329

${ }^{5}$ Alexey Yurievich Molyanov, Moscow University of the Ministry of Internal Affairs of Russia named by V.Ya. Kikot. ORCID: https://orcid.org/0000-0002-7652-0753
}

Corresponding author: dmitriy.a.ivanov@bk.ru 
Dmitriy Aleksandrovich Ivanov, Marina Vladimirovna Sokolova, Oksana Leonidovna Podustova,

Pavel Vladimirovich Fadeev, Alexey Yurievich Molyanov

\title{
Penyitaan Properti sebagai Cara untuk Memastikan Kompensasi atas Kerusakan yang Disebabkan oleh Kejahatan: Teori dan Praktik
}

\begin{abstract}
Abstrak
Penulis mempertimbangkan ketentuan teoritis dan menganalisis contoh praktis dari kegiatan badan investigasi untuk menyita properti dalam proses pra-persidangan dalam kasus pidana. Relevansi topik ini ditentukan oleh fakta bahwa salah satu kegiatan prioritas badan investigasi pendahuluan saat ini adalah memastikan hak dan kepentingan sah warga negara terhadap perambahan kriminal. Kemungkinan pemberian ganti rugi kepada korban kerugian yang diakibatkan oleh suatu tindak pidana dalam hukum acara pidana merupakan jaminan perlindungan terhadap hak-hak tersebut dan turut menunjang terlaksananya tujuan proses pidana. Berdasarkan hasil yang diperoleh, penulis menyimpulkan bahwa perlu lebih meningkatkan praktik penegakan hukum dan norma-norma peraturan perundang-undangan pidana dan acara pidana untuk meningkatkan efisiensi penyelesaian masalah identifikasi harta benda yang dapat disita. Sehubungan dengan itu, diusulkan untuk mengubah Bagian 3 Pasal 104.1 KUHP Federasi Rusia, yang mengatur kemungkinan penyitaan properti, terlepas dari kesadaran akan hubungan sebab akibat antara tindakan yang dilakukan dan adanya uang atau properti lainnya.

Kata Kunci: Proses pidana; Tindakan paksaan prosedural; Peneliti; Penanya; Klaim sipil.
\end{abstract}

\section{Наложение ареста на имущество в целях обеспечения возмещения вреда, причиненного преступлением: теория и практика}

\begin{abstract}
Аннотация
Авторами рассматриваются теоретические положения $и$ анализируются практические примеры деятельности органов расследования по наложению ареста на имущество в досудебном производстве по уголовным делам. Актуальность данной темы определяется тем, что одним из приоритетных направлений деятельности органов предварительного следствия в настоящее время является обеспечение прав и законных интересов граждан от преступных посягательств. Возможность возмещения потерпевшим вреда, причиненного преступлением, в уголовно-процессуальном праве является гарантией защиты данных прав и способствует реализации назначения уголовного судопроизводства. На основе полученных результатов авторы приходят к выводу о необходимости дальнейшего совершенствования правоприменительной практики и норм уголовного и уголовнопроцессуального законодательства в целях повышения эффективности решения задач по установлению имущества, на которое может быть наложен арест. В связи с чем предлагают внести в ч. 3 ст. 104.1 УК РФ изменения, предусматривающие возможность конфискации имущества, вне зависимости от осведомленности о причинно-следственной связи между совершенным деянием и наличием денег или иного имущества.
\end{abstract}

Ключевые слова: Ключевые слова: уголовное судопроизводство, меры процессуального принуждения, следователь, дознаватель, гражданский иск 


\section{A. INTRODUCTION}

A multi-faceted and consistent activity aimed at establishing the property that can be seized by the courts in order to ensure a civil claim and compensation for the damage caused by the crime to the victims is carried out by the investigator, the inquirer at all stages of the preliminary investigation.

An effective procedural way to ensure a civil claim in criminal proceedings is the use of such a preventive measure of procedural coercion as the seizure of property.

\section{B. METHODS}

The methodological basis of the study of the seizure of property in pretrial proceedings is determined by the subject of the study and is explained by the use of special legal methods: historical-legal, analysis, synthesis, system, formal-legal, sociological (questionnaire survey, conversation, interviewing).

The historical-legal method allowed to consider the seizure of property as a procedural action carried out in order to ensure compensation for damage caused by a crime, taking into account the constantly improving needs of both theory and practice.

Through the use of methods of analysis and synthesis, real information was obtained regarding the effectiveness of the seizure of property as the main method of compensation for damage caused by a crime.

The use of the formal legal method allowed us to characterize the existing situation associated with a number of problems that arise when seizing property in the practical activities of the investigation bodies to ensure a civil claim in criminal cases, as well as to analyze the identified problems and suggest the best ways to resolve them.

The sociological method of research allowed us to obtain real results of empirical research, as well as to analyze, systematize and generalize them.

\section{RESULT AND DISCUSSION}

When it comes to the availability of information about the property subject to seizure, it seems relevant to the authors to highlight the issue concerning the sources of obtaining such information. It will be timely to indicate the institutions 
Dmitriy Aleksandrovich Ivanov, Marina Vladimirovna Sokolova, Oksana Leonidovna Podustova,

Pavel Vladimirovich Fadeev, Alexey Yurievich Molyanov

and organizations in which it is possible to obtain information of interest to the investigator, the inquirer, taking into account the specifics of a particular property that is supposed to be seized (Sokolova, 2018, p. 76).

These sources are:

- The Federal Service for State Registration, Cadastre and Cartography (Rosreestr) (Government of the Russian Federation, 2009), where it is possible to obtain information about the existing rights to real estate and transactions with it, as well as about participation in shared-equity construction (State Duma of the Federal Assembly of the Russian Federation, 2004). The territorial bodies of Rosreestr and the offices of the Bureau of Technical Inventory (BTI) also have information about the availability of land plots registered to a particular person or to their relatives. In particular, as a successful solution to this problem, the materials of the criminal case No. 108652 should be mentioned, investigated in the Investigative Department of the Ministry of Internal Affairs of the Chuvash Republic against Sh., who is the founder and director of LLC "Star21. com", LLC "Pride", LLC "Drive-Auto" and LLC "Ipsum", on the grounds of crimes under Part 4 of Article 196, Part 4 of Article 159, Part 2 of Article 201 of the Criminal Code of the Russian Federation on the facts of fraud against individuals and deliberate bankruptcy, which caused property damage in the amount of 306 million rubles. As a result of the proper and prompt organization of the joint work of the preliminary investigation bodies and the territorial bodies of Rosreestr, third parties have been identified, where four land plots actually belonging to the accused are registered. The discovered land plots were seized, thus security measures were taken in the amount of 332 million rubles (Materials of the criminal case No. 108652, 2016);

- The Federal Tax Service (FTS of Russia) (Government of the Russian Federation, 2004), which has information about registered legal entities and individual entrepreneurs. An example of the proper work of the preliminary investigation bodies and the Federal Tax Service of Russia to ensure compensation for damage caused by criminal acts is the materials of the criminal case No. 10/14138, initiated in the Investigative Department of the Ministry of Internal Affairs of the Republic of North Ossetia-Alania under Part 4 of Article 159 of the Criminal Code of the Russian Federation on the fact of embezzlement of M. and S. by illegally reimbursing value-added tax (VAT) by providing information about the commission of imaginary transactions between organizations controlled by criminals of budget funds in the amount of 265 million 911 thousand rubles. In order to compensate for the damage caused to the budget of the Russian Federation, the location was established and the 
property of the accused was seized for a total amount of 376 million 356 thousand rubles, exceeding the total amount of property damage caused (Materials of the criminal case No. 10/14138, 2015);

- The State Road Safety Inspectorate of the Ministry of Internal Affairs of Russia, which can provide information about registered vehicles (with an internal combustion engine displacement of more than $50 \mathrm{ccs}$ and a maximum design speed of more than $50 \mathrm{~km} / \mathrm{h}$, as well as trailers for them intended for driving on public roads);

- banks and credit organizations (Supreme Soviet of the RSFSR, 1990) that have information about banking operations and other transactions in rubles and in foreign currency, as well as about leasing special premises or safes and cells located in them, intended for storing documents and other valuables;

- in notary offices, notaries engaged in private practice, and officials authorized to perform notarial actions, one can get information (documents) about the notarial actions performed;

- in the divisions of the federal executive authority-Rosgvardiya (information about registered weapons and their collections (State Duma of the Federal Assembly of the Russian Federation, 1996);

- The National Central Bureau of Interpol (President of the Russian Federation, 1996) has information from other states on the sale of stolen property (Ministry of Internal Affairs of Russia, Ministry of Justice of Russia, FSB of Russia, FSO of Russia, FSKN of Russia \& FCS of Russia, 2006; Hong et al., 2020). At the same time, in the course of preliminary verification of reports of crimes and offenses in the field of economy, as well as in the course of operational search activities in cases of this category, official names of legal entities registered abroad can be obtained through the National Security Service of Interpol. In addition, the NCB of Interpol has information about their legal addresses, numbers, and registration dates; surnames and names of individuals-managers (in some cases - founders, shareholders); areas of activity; the size of the authorized capital; information about the activities of legal entities and individuals of a criminal nature;

- when investigating criminal cases of economic and corruption-related crimes, information is requested from Rosfinmonitoring units about the availability of accounts, the movement of assets, property, and other valuables of suspects (accused), as well as their close relatives. This service performs the functions of countering the legalization (laundering) of proceeds from crime and the financing of terrorism, as well as the development of state policy, legal 
Dmitriy Aleksandrovich Ivanov, Marina Vladimirovna Sokolova, Oksana Leonidovna Podustova,

Pavel Vladimirovich Fadeev, Alexey Yurievich Molyanov

regulation, and coordination of activities in this area of other federal executive bodies. An example of timely treatment and effective interaction of the preliminary investigation bodies with the territorial divisions of Rosfinmonitoring is the criminal case investigated in the Investigative Department of the Ministry of Internal Affairs of Russia in the Arkhangelsk region in 2015 on charges of P. committing crimes under Part 4 of Article 159, Part 2 of Article 174.1 of the Criminal Code of the Russian Federation. In the course of the preliminary investigation in order to establish the fact of the pretense of the sale transaction to the accused $P$. the investigator sent a request to the MRU of Rosfinmonitoring in the North-Western Federal District with the formulation of specific tasks to establish the parameters of the transaction. The results obtained on the alleged transaction were used in the preliminary investigation, and on the building worth 5 million 911 thousand rubles an arrest was imposed, which allowed for $100 \%$ compensation for the property damage caused (Materials of the criminal case No. 14010342, 2015).

Indicating the main state bodies where there is the information of interest to the investigator, the inquirer about the property that can be seized, it should be noted that, starting from the initial stage of the preliminary investigation, it is they who should organize the immediate conduct of investigative actions aimed at identifying the property and funds subject to arrest, in order to subsequently satisfy the claims of civil plaintiffs in criminal cases. It is also necessary to establish the movement of stolen funds on the settlement accounts of fictitious organizations, determine the final recipients of the stolen funds, as well as specific persons who are beneficiaries of transactions made with these funds.

Given that persons who have committed crimes take measures to conceal the stolen property and property owned by them, it will be appropriate for the investigator, the inquirer to instruct employees of operational units to carry out a complex of both public and secret operational search measures (surveillance, wiretapping, etc.) aimed at establishing the location of such property.

It is advisable for officials conducting preliminary investigations to use modern information databases (insurance companies, credit bureaus, etc.), as well as information contained in the accounts of suspects (accused) of social networks (Odnoklassniki, VKontakte, Facebook, Instagram, etc.) in order to obtain reliable data on the possible possession or disposal of property that may be seized.

In cases where the object of theft is money stolen from the current accounts of individuals and legal entities, it is advisable to search for them by requesting bank statements on current accounts. At the same time, investigators and 
inquirers are recommended to apply to the district courts with petitions to seize the stolen funds in order to prevent their subsequent transfer and cashing and legalization (Pushkarev et al., 2020).

In criminal cases where mobile devices (phones, tablet computers) are the subject of theft, it is advisable to apply to the courts with petitions for permission to obtain information from mobile operators about the connections made from stolen mobile devices and about the persons in whose use the stolen property is located. The subsequent seizure of the specified property carried out in the course of such investigative actions as a search, personal search, seizure, will also be justified.

In order to avoid difficulties or impossibility of execution of the sentence, the investigator, the inquirer must take measures to identify and search for the property that is being seized. Employees of operational divisions of the internal affairs bodies may be involved in the search for property, along with specialists. If it is necessary to search for and establish the location of the property, employees of operational units have the right to conduct operational search activities, including using information systems, audio-video recordings, film photography, and search equipment. The most effective is the use of search technology, which allows you to detect the desired objects in the hiding environments: soil, water, vehicles, etc. The complex use of these tools allows to identify, study and analyze events and facts related to the search for the debtor's property.

When investigating crimes on the facts of illegal acquisition of real estate, investigators, inquirers need to take measures to stop further transactions with the specified real estate object in order to compensate the property damage to the victims. At the same time, real estate objects should be recognized as material evidence, and reports on the termination of registration of transactions with these real estate objects should be sent to the Office of the Federal Service for State Registration, Cadastre and Cartography. Simultaneously, and as quickly as possible, to submit a petition to the court for the seizure of property (Epikhin, 2012, p. 16-17).

Confirmation of the successful implementation of this area of activity of officials conducting a preliminary investigation can serve as the materials of the criminal case investigated in the Investigative Department of the Department of Internal Affairs for the CAO GU of the Ministry of Internal Affairs of Russia in Moscow, from which it follows that M. no later than November 21, 2012, in a place not established by the investigation, entered into preliminary collusion with persons not established by the investigation, aimed at acquiring ownership 
of an apartment located at Moscow, Lavochkina str., XX, bldg. X, sq. XXX, owned by $B$. In the future, realizing his criminal intent, $M$. together with unidentified accomplices, using a fake passport and posing as personal data of B., by deception concluded a contract with $\mathrm{K}$. for the purchase and sale of the specified apartment. Thus, M., together with the co-conspirators who were not identified by the investigation, disposed of someone else's property by deception, depriving $B$. of the right of ownership of the apartment. In the course of the preliminary investigation, the victim B. a civil claim was filed, and in order to ensure the execution of the sentence in the part of the civil claim, the specified apartment was seized in the form of a ban on disposing of it, and the Office of the Rosreestr for Moscow was sent a ban on state registration of transactions with the specified apartment (Materials of the criminal case No. 777524, 2012).

Investigating the issues of seizure of property in order to ensure compensation for damage caused by a crime, the authors consider it necessary to point out that in order to clarify the provisions of Part 1 of Article 115 of the Criminal Procedure Code of the Russian Federation, the resolution of the Constitutional Court of the Russian Federation No. 1-P of 31.01.2011 contains a provision that Part 1 of Article 115 of the Criminal Procedure Code of the Russian Federation, which provides for the execution of a sentence in part of a civil claim, the seizure of property of persons who are legally liable for the actions of a suspect or accused, does not contradict the Constitution of the Russian Federation (Constitutional Court of the Russian Federation, 2011).

At the same time, it is important to note that when investigating various types and categories of crimes, investigators and inquirers should apply the measure of procedural coercion in question everywhere (if there are legal grounds for this).

It is also worth paying attention to the fact that the seizure of property in some cases encourages suspects and accused persons to voluntarily compensate for the damage caused by the crime. So, in the criminal case No. 16280140 on the charge of the chief accountant of LLC "Medved" B. of embezzlement of funds in the amount of 400,000 rubles, at the initial stage of the investigation, the property belonging to the latter was established, which was seized. As a result, the accused voluntarily compensated for the damage caused by the crime (Podustova, 2019, p. 114-115).

In the course of studying the investigative and judicial practice, the authors came to the conclusion that many decisions on the seizure of property and money are appealed. This is quite understandable since the accused pursue the goal of preserving what they own and dispose of, even if on illegal grounds, 
and do not want to compensate for the property damage caused by their criminal activities. The courts, in this case, examining the materials of such complaints, as a rule, make various decisions, but most often recognize the arrest imposed by the investigator, the inquirer on the property as legitimate and justified.

The Cassation Board for criminal cases of the Moscow City Court considered at the court session the case on the cassation appeal of the representative of S. against the decision of the Meshchansky District Court of Moscow of July 14, 2011, which K. was denied in the request to cancel the arrest for funds in the amount of 4,481,747 rubles. 67 kopecks., located in the current account of Sberbank of Russia in Moscow. From the submitted materials, it followed that the verdict of the Meshchansky District Court of Moscow of May 11, 2010, which entered into legal force, was the specified funds were seized and levied for compensation of property damage caused to the victims. Having studied the submitted materials, the court came to the correct conclusion that there were no grounds for satisfying the request to cancel the seizure of funds. On the basis of the above, the judicial board determined the decision of the Meshchansky District Court of Moscow of July 14, 2011, to leave unchanged, and the cassation appeal - without satisfaction (Appeal decision of the Judicial Board, 2011).

However, despite the correct actions of investigators, interrogators, aimed at establishing the property of the accused (suspects), which can be seized, the measures taken do not always achieve their final goal - compensation for the damage caused by the crime due to the fact that often the courts do not resolve the question of the fate of the arrested property at all, despite the direct indication of this in paragraph 11, Part 1, Article 299 of the Criminal Procedure Code of the Russian Federation (Pushkarev et al., 2020).

So, in the criminal case No. 12013270676, investigated in the Investigative Department of the Ministry of Internal Affairs of Russia in the Ryazan region on charges of the director of LLC "Zodchestvo" M. in the illegal alienation of land plots worth 17,700,000 rubles., owned by B., the court seized these plots in order to compensate for the damage caused. The court's verdict of November 25, 2014, which found M. guilty under Part 2 of Article 165 of the Criminal Code of the Russian Federation and imposed a sentence of imprisonment for a period of 3 years with a probation period of 2 years, did not make a decision on the seized property (Materials of the criminal case No. 12013270676, 2015).

Another similar fact was revealed by the authors in the course of studying the verdict of the Kuibyshev District Court of Omsk. According to the content of the sentence, the chief accountant of FSUE "Prevention" Sh. was found guilty of 
embezzlement by the deception of 5.7 million rubles belonging to this enterprise. The verdict of the court does not contain a decision regarding the apartment of the spouse of the accused Sh., which was seized during the preliminary investigation in order to secure a civil claim (Criminal case No. 27236-15, 2015).

In the light of the above and the above examples of investigative practice, it seems reasonable and appropriate to further improve the legislation. In particular, it is proposed to amend Part 3 of Art. 1041 of the Criminal Code of the Russian Federation regarding the possibility of confiscation of property owned by relatives of the suspect (accused) or other persons, which is seized by the court, if it is proved that it was purchased with money, the presence of which is due to criminal activity, regardless of whether they are aware of the presence of a causal relationship between the committed act and the presence of money or other property.

At the same time, for a more effective application of the theoretical foundations of the resolution of a civil claim in the practical plane of the criminal procedure sphere of activity, it is necessary to make changes and additions to the current legislation.

\section{CONCLUSIONS}

In order to improve the efficiency of solving the tasks of identifying property that can be seized by the courts in order to secure a civil claim, other property penalties, or possible confiscation in criminal cases, it seems appropriate to further improve law enforcement practice and the norms of criminal and criminal procedure legislation. In particular, given the evolving investigative and judicial practice, it is possible to make Part 3 of Article 1041 of the Criminal Code of the Russian Federation amendments providing for the possibility of confiscation of property owned by relatives of the accused (suspect) or other persons, which is seized by the court, if it is proved that it was purchased with funds, the appearance of which is due to criminal activity, regardless of whether they are aware of the presence of a causal relationship between the acquired property and the fact of committing a crime.

\section{REFERENCES}

Appeal decision of the Judicial Board on criminal cases of the Moscow city court on September 28, 2011 No. 22-12048. Retrieved from https://rospravosudie.com/ (date of access: 10.02.2021).

Constitutional Court of the Russian Federation. (2011). Resolution of the Constitutional Court of the Russian Federation of January 31, 2011 No. 1-P "On 
the case of checking the Constitutionality of the Provisions of Parts One, Three and Nine of Article 115, paragraph 2 of Part One of Article 208 of the Criminal Procedure Code of the Russian Federation and paragraph Nine of paragraph 1 of Article 126 of the Federal Law "On Insolvency (Bankruptcy)" in connection with the complaints of the closed Joint Stock Company "Real Estate-M", Limited Liability Company "Solomatinskoe Khlebopriemnoe enterprise" and citizen L. I. Kostareva". Sobranie Zakonodatel'stva Rossiiskoi Federatsii [SZ RF] [Collection of Legislation of the RF]. 2011, No. 6, Item 897.

Criminal case No. 27236-15. (2015). Archive of the Kuibyshev district Court of Omsk.

Epikhin, A.Yu. (2012). The imposition of arrest on property as a measure to ensure the execution of a sentence in the form of a significant fine. Russian investigator. No. 16, 15-20.

Government of the Russian Federation. (2004). Resolution of the Government of the Russian Federation of September 30, 2004 No. 506 "On approval of the Regulations on the Federal tax service". Rossiiskaia Gazeta [Ros. Gaz.] 06.10.2004 No. 3596 (Russ.).

Government of the Russian Federation. (2009). Resolution of the Government of the Russian Federation of June 1, 2009 No. 457 "On the Federal Service for State Registration, Cadastre and Cartography". Sobranie Zakonodatel'stva Rossiiskoi Federatsii [SZ RF] [Collection of Legislation of the RF] 22.06.2009, No. 25, Item 3052.

Hong, N.T.L., Tuyen, T.V, Pushkarev, V.V., Fadeev, P.V. \& Khmelev, S.A. (2020). Criminal prosecution of persons who do not speak the language of criminal process. Revista Inclusiones. Vol. 7, No. S3-3, 121-125.

President of the Russian Federation. (1996). Decree of the President of the Russian Federation of July 30, 1996 No. 1113 "On the participation of the Russian Federation in the activities of the International Criminal Police Organization Interpol". Retrieved from http://www.kremlin.ru/acts/bank/9805

State Duma of the Federal Assembly of the Russian Federation. (1996). Federal law of December 13, 1996 No. 150-FZ “On weapons". Sobranie Zakonodatel'stva Rossiiskoi Federatsii [SZ RF] [Collection of Legislation of the RF] 16.12.1996, No. 51, Item 5681.

State Duma of the Federal Assembly of the Russian Federation. (2004). Federal Law of December 30, 2004 No. 214-FZ "On participation in shared-equity construction of apartment buildings and other real estate objects and on amendments to certain legislative acts of the Russian Federation". Sobranie Zakonodatel'stva Rossiiskoi Federatsii [SZ RF] [Collection of Legislation of the RF] 03.01.2005, No. 1 (Part I), Item 40. 
Dmitriy Aleksandrovich Ivanov, Marina Vladimirovna Sokolova, Oksana Leonidovna Podustova,

Pavel Vladimirovich Fadeev, Alexey Yurievich Molyanov

Supreme Soviet of the RSFSR. (1990). Federal law of December 2, 1990 No. 395-I “On banks and banking activity". Zakonodatel'stva Rossiiskoi Federatsii [SZ RF] [Collection of Legislation of the RF] 05.02.1996, No. 6, Item 492.

Materials of the criminal case No. 777524. (2012). Investigation Department ATC CAO GU MVD of Russia in Moscow.

Materials of the criminal case No. 10/14138. (2015). Investigation Department of the MIA for the Republic of North Ossetia-Alania (Review of the Investigation Department of the MIA of Russia "On the status of joint work for the establishment, removal and return of victims of property and funds", dated 4 may 2016, No. 17/2-11237).

Materials of the criminal case No. 14010342. (2015). Investigative Department of the Ministry of Internal Affairs of Russia in the Arkhangelsk region.

Materials of the criminal case No. 12013270676. (2015). Investigative Department of the Ministry of Internal Affairs of Russia in the Ryazan region.

Materials of the criminal case No. 108652. (2016). Investigation Department of the Affairs of the Chuvash Republic (Review of the Investigation Department of the MIA of Russia "On the status of joint work for the establishment, removal and return of victims of property and funds", dated 4 may 2016, No. 17/2-11237).

Ministry of Internal Affairs of Russia, Ministry of Justice of Russia, FSB of Russia, FSO of Russia, FSKN of Russia \& FCS of Russia (2006). Order of October 6, 2006 No. 786/310/470/454/333/971 "On approval of the Instructions for organizing information support for cooperation through Interpol". Bulletin of normative acts of federal executive authorities, 20.11.2006, No. 47.

Podustova, O.L. (2019). Ensuring in the course of the preliminary investigation compensation to the victims of the harm caused by the crime: abstract dis. ... candidate of legal sciences. Moscow University of the Ministry of Internal Affairs of the Russian Federation, Moscow, 201 p.

Pushkarev, V.V., Fadeev, P.V., Khmelev, S.A., Van Tien, N., Trishkina, E.A. \& Tsviliy-Buklanova, A.A. (2019). Crimes in the Military-Industrial Complex (MIC). Technology and Engineering. Vol. 8, No. 3, 7950-7952.

Pushkarev, V.V., Boziev, T.O., Esina, A.S., Zhamkova, O.E., Chasovnikova, O.G. (2020). Criminal prosecution for crimes committed in the banking industry. Laplage em Revista. Vol. 6, No. Extra C, 244-248. DOI: 10.24115/S2446-622020206Extra-C647p.244-248

Sokolova M.V. (2018). The activity of the investigator on the seizure of property: abstract dis. ... candidate of legal sciences. Moscow University of the Ministry of Internal Affairs of the Russian Federation, Moscow. 